This item was submitted to Loughborough's Research Repository by the author.

Items in Figshare are protected by copyright, with all rights reserved, unless otherwise indicated.

\title{
Public to private and back again: the role of politicians' wives in British election campaign coverage
}

PLEASE CITE THE PUBLISHED VERSION

http://dx.doi.org/10.1080/14680777.2015.1105841

\section{PUBLISHER}

(c) Taylor \& Francis

\section{VERSION}

AM (Accepted Manuscript)

\section{PUBLISHER STATEMENT}

This work is made available according to the conditions of the Creative Commons Attribution-NonCommercialNoDerivatives 4.0 International (CC BY-NC-ND 4.0) licence. Full details of this licence are available at: https://creativecommons.org/licenses/by-nc-nd/4.0/

\section{LICENCE}

CC BY-NC-ND 4.0

\section{REPOSITORY RECORD}

Harmer, Emily. 2019. "Public to Private and Back Again: The Role of Politicians' Wives in British Election Campaign Coverage". figshare. https://hdl.handle.net/2134/19811. 


\title{
Public to private and back again: The role of politicians' wives in British election campaign coverage.
}

\begin{abstract}
The wives of politicians are a longstanding feature of electoral campaign coverage in the UK, and yet until now there has been no systematic study examining their role and mediated representation in political reporting. By drawing upon a sample of 630 newspaper items from five daily newspapers, this article will demonstrate that between 1918 and 2010 the representation of political wives has changed in three main ways. Firstly, their role in the campaign process changed from focusing more on their political function as active campaigners, to becoming more focused on their private lives. Secondly the coverage has narrowed from focusing on a broad range of politicians’ wives, to being centred almost entirely on the spouses of political party leaders. The final change is that the press reportage of politicians' spouses has become increasingly negative and critical of their presence on the campaign trail.
\end{abstract}

Keywords: Politicians’ Wives, British politics, public and private spheres, gender

\section{Main article}

The way women are depicted in news media sends out important messages about their place and role in society. The majority of work in this area focuses on the US and European context, and tends to analyse contemporary representations of women in politics from the 1990s onwards. Many scholars have noted that the activities of female politicians receive less news coverage than those of men and, secondly, news descriptions refer to their appearance, or to the men in their lives, rather than to their independent qualities and achievements (Norris, 1997; Braden, 1996; Ross, 2002; Gill 2007). Ultimately such scholarship has demonstrated the ways in which female political actors are always women first and politicians second. 
These representations articulate a particular ideological view about men and women; far from being neutral, the imagery and language of mediated politics is heavily gendered and reinforces the idea of male as the norm, whilst women are regarded as outsiders or novelties (Sreberny-Mohammadi and Ross, 1996).

Although there is a significant body of literature that analyses the mediated representation of women politicians, scholarly work has tended to be scarcer when it comes to the portrayal of informal political actors, such as the spouses of politicians. These women often have no formal role in political decision making; however the ways in which they appear in news discourses speak volumes about the relationship between gender, media and politics. This article aims to contribute to the wider discussion about the ways in which representational politics remains gendered, by exploring the way the British press provides particular vocabularies, images and concepts with which to make sense of the political world and the place of men and women within it (Holland, 2004). There has been scant literature which systematically studies the presence and role of female relatives in media coverage of politics. The vast majority of the literature focuses upon the US First Lady (Borrelli, 2011; Beasley, 2005; Winfield, 1997) and those which do not tend to focus upon the spouses of party leaders. In contrast, it is commonly assumed that the spouses of British Prime Ministers have been largely confined to the private sphere until the 1990s (Stanyer, 2007) with the possible exceptions of Mary Wilson and Dennis Thatcher (Seymour-Ure, 2003).

This article aims to provide a systematic content and textual analysis of the role of politicians' female relatives in election coverage in Britain since 1918. The article aims to answer the following research questions: how are the female relatives of politicians portrayed in British political news? To what extent are can they be considered 'political actors' in the formal sense and how has this changed over time? The article will show that in fact female relatives, and politicians' wives in particular, have been well established actors in election coverage for most of the twentieth century. Indeed, whilst their presence in campaign news has altered very little, their representation has changed a great deal.

$\underline{\text { Public and Private Politics: }}$ 
Feminist scholars argue that the political domain and its activities have historically been constructed in contrast to the private, domestic sphere. Van Zoonen (1998) argues that such a distinction between 'public' and 'private' is a fairly recent historical construction and that it is tied to the division of labour between men and women in the family. Siltanen and Stanworth (1984) argue that this separation of public and private promotes a set of dichotomies which disadvantage women. These are defined as: political-apolitical, publicprivate, and male-female. Such dichotomies construct the abstract public citizen as male in the sense that he performs traditionally masculine roles and has male characteristics. He is universal, rational and is concerned with the public interest. In contrast the female, noncitizen's concerns are private and domestic and she is emotional, irrational and weak (Lister, 1997).

Landes (1998) notes that the division between the public and private spheres meant that a whole range of concerns came to be labelled private and treated as improper subjects for public discussion. The feminist movement, and the incorporation of women into the formal public sphere as politicians and voters, has meant that the boundaries between the public and the private, and the political and the personal, have become blurred: demonstrating that the line between public and private is not fixed, but constantly being renegotiated (Landes, 1998). Feminists further argue that women made the public sphere possible by undertaking the provision of care, reproduction and other unpaid (and therefore unrecognised) duties (Lister, 1997). When women were admitted to the public sphere, they did so on different terms than men, because they were still expected to fulfil their private roles. This is central to the way in which political relatives function in news discourses around politics.

In her research into the role of US First Ladies, Borelli (2011) claims that the role of political wives is unavoidably gendered, since political leadership has always been associated with masculine characteristics such as self-reliance, competitiveness and ambition. Therefore, effective political leaders are expected to embody the best qualities of the rational, universal public sphere. In order to enhance these credentials it has often been necessary to juxtapose these masculine qualities with those of their wives who, in turn, are meant to represent feminine characteristics associated with the private sphere. This is why, Borelli (2011) argues, wives who engage in public sphere activities outside of traditionally feminine areas like charity work, risk undermining the political leadership of their partners by undermining masculinity. 
Although Borelli (2011) is referring to the highly masculinised role of president, parallels can be made with the prime ministerial system within the UK, where increased attention has been lavished on party leaders at the expense of other politicians with much of this increased attention concerning their private lives (Stanyer, 2013). Since the role of female relatives in politics has largely been under-theorised in the UK context, this article will draw upon the US literature in order to make sense of the media representations that are the subject of its analysis. It is the aim of this article to demonstrate that the role of politicians' wives in electoral discourse reflects this traditional divide between the public and private, along with the response from media commentators when these rules are transgressed.

\section{The visibility of politicians' families}

Winfield (1997) describes the historical development of the first lady role in US politics. She argues that first ladies are framed in four ways. Firstly, they are expected to fulfil the role of loyal escort, accompanying their husband but with no independent function. Secondly, they are expected to perform a protocol role, acting as hostess for visiting dignitaries and attending social, ceremonial and diplomatic events. The third frame, which developed in the twentieth century, emphasises their role in charitable causes and volunteer work. The fourth is their role in acting as an advisor and helping to formulate policy. This last role is highly controversial, and is perhaps most associated with Hillary Clinton whose political power and influence were often constructed as illegitimate and dangerous. Scharrer and Bissell (2001) analysed media coverage of three first ladies, Nancy Reagan, Barbara Bush and Hillary Clinton and found that the more politically active a first lady was deemed to be, the more negative coverage she received.

In Britain, similar accusations have been levelled at former Prime Minister Tony Blair's wife Cherie Booth, who received conflicting representations in news coverage during her husband's premiership. Clinton and Booth are similar in a number of ways; both women 
deviate from the traditional First Lady roles described by Winfield (1997) and both women were keen to maintain their own surnames despite news coverage tending to emphasise their married name (Page, 2003). Seymour-Ure (2003) also notes that Booth is the first wife of a British Prime Minister to have her own press secretary appointed to her by Number 10, which implies her role has become more akin to that of a First Lady. Reyes (2003) argues that Booth was subjected to a high volume of hostile coverage from conservative tabloid newspapers which characterised her as an excessively influential woman who manipulated her husband's position for her own benefit. Politicians’ wives in other countries have also been criticised for seeming overly engaged in politics. Sarah Netanyahu was treated negatively by the Israeli press when it felt she had overstepped her authority (Halevi, 2003), and similar examples can be found in Turkey (Cinar, 2014) and in the Arab world (Ibroscheva, 2013).

Much of the literature which discusses the role of politicians' spouses suggests that their visibility has increased due to an increase in personalised political coverage (Stanyer, 2013). For example Seaton (2003) argues that scrutiny of personal relationships has increased in the UK, citing historic examples which would have caused embarrassment had they been widely reported, such as Lloyd George’s long running affair with Frances Stevenson and the fact that Violet Attlee was a dedicated Conservative voter.

Reyes (2003) and Adcock (2010) both argue that the mediated representation of his wife and children are central to the mediation of Blair's public image and therefore any criticism of Booth is, by extension, a criticism of her husband. Blair sought to portray his wife as an ordinary working mother in order to enhance his own ordinariness (Reyes, 2003). Higgins and Smith (2013) argue that the wives of party leaders were presented in a similar way during the 2010 British general election. The authors discuss the deliberate marketing of Sarah Brown and Samantha Cameron and argue that these women were mobilised in an attempt to counteract the negative aspects of their husband's personalities. Samantha 
Cameron was constructed as middle class and 'ordinary' in order to make her husband seem less upper class and out of touch; while Sarah Brown was intended to humanise her husband by making him appear more warm and caring. Winfield and Friedman (2003) make similar conclusions about the representation of the wives of candidates for the Presidency and VicePresidency in the 2000 US election. The authors analysed the news coverage of Laura Bush, Tipper Gore, Lynne Cheney and Hadassah Lieberman and their results suggest that three of the four women were introduced as loyal escorts to their husbands on the campaign trail. Furthermore, the wives were central to the campaign, often compensating for perceived weaknesses of their husbands'. Spouses of European leaders have also been known to receive media attention during election time. For example, during the 2002 presidential election in France, magazines featured pictorial spreads of the candidates and their wives engaged in everyday activities like cooking and relaxing at home (Kuhn, 2004). Likewise, in Germany, Karin Stoiber and Doris Schröder-Köpf were both employed to appeal to women voters during the 2002 election (Holtz-Bacha, 2004). Given that such women are frequently the subject of news coverage in contemporary politics and the literature suggests that they have recently become an established part of political campaigning, their role in political news is worthy of more scholarly investigation than they have thus far received.

\section{Method}

The article draws upon a quantitative and qualitative content analysis of five national UK daily newspapers, the Daily Telegraph, The Guardian, The Daily Herald (which became The Sun in 1964), the Daily Mail and the Daily Mirror. These titles were selected because they reflect the full range of press partisanship in Britain and because they have all been publishing since before 1918, allowing for a meaningful historical comparison. The content analysis sampled the week before all 25 elections which took place between 1918 and 2010 . The week before each election was sampled in order to see what role, if any, the wives played in formal campaigning activities. All items which were entirely about the election and featured more than one mention of a female actor were coded. Female relatives were only 
counted as such if the news item contained an explicit reference to a familial relationship with a politician. Variables pertinent to this article include, the theme of the coverage, whether the item mentions some aspect of their personal life and whether there is an explicit evaluation of the relative.

The vast majority of items focused upon women politicians and voters, but there were 653 separate items about politicians' relatives which comprise the data discussed in this article. The number of items dedicated to female relatives is highest during the elections that take place during the interwar years. The subsequent decline reflects the changing conventions in newspapers as their relative size and space for political news reduces so although there is obviously some variation over time, their proportion of the coverage (compared to items about women politicians and voters) changes very little, ranging from between $10 \%$ and $20 \%$ of items which contained significant references to women. The breakdown for each election is displayed in Table 1:

Table 1: Number of items about relatives across newspapers, 1918-2010

\begin{tabular}{|c|c|c|c|c|c|c|}
\hline & \multicolumn{5}{|c|}{ Newspaper } & \multirow[t]{2}{*}{ Total } \\
\hline & Daily Mirror & The Guardian & Daily Telegraph & Daily Mail & $\begin{array}{l}\text { Daily Herald/The } \\
\text { Sun }\end{array}$ & \\
\hline 1918 & 2 & 5 & 1 & 3 & 0 & 11 \\
\hline 1922 & 4 & 6 & 13 & 11 & 1 & 35 \\
\hline 1923 & 7 & 15 & 12 & 17 & 5 & 56 \\
\hline 1924 & 4 & 10 & 14 & 14 & 13 & 55 \\
\hline 1929 & 1 & 8 & 11 & 3 & 5 & 28 \\
\hline 1931 & 5 & 7 & 13 & 15 & 10 & 50 \\
\hline 1935 & 1 & 8 & 14 & 12 & 4 & 39 \\
\hline 1945 & 0 & 4 & 8 & 0 & 3 & 15 \\
\hline 1950 & 0 & 4 & 10 & 5 & 4 & 23 \\
\hline 1951 & 1 & 2 & 8 & 6 & 2 & 19 \\
\hline 1955 & 0 & 7 & 4 & 5 & 1 & 17 \\
\hline 1959 & 2 & 6 & 13 & 4 & 1 & 26 \\
\hline 1964 & 2 & 5 & 5 & 8 & 5 & 25 \\
\hline 1966 & 3 & 8 & 6 & 2 & 3 & 22 \\
\hline
\end{tabular}




\begin{tabular}{|l|r|r|r|r|r|}
\hline 1970 & 2 & 9 & 5 & 4 & 3 \\
1974 \\
F
\end{tabular}

The content analysis focuses on to what extent politicians' relatives are portrayed as active campaigners and the explicit evaluation of these activities. This data was then corroborated by a qualitative analysis was conducted on items which were typical examples of electoral coverage for each election. A constant comparison of items over time demonstrates the subtle ways in which the themes and vocabularies associated with political spouses has changed.

$\underline{\text { From "Ideal election wife" }{ }^{1} \text { to "just another political wife" } 2 \text { in three stages }}$

The representation of politicians' wives has altered in three main ways. Firstly, their role in the campaign process changed from focused more on their political function as active campaigners to more interest in their private lives. Furthermore, the coverage has narrowed from a broad range of politicians' wives, to being centred almost entirely on the spouses of political party leaders; and finally, the press reportage of politicians' spouses has become increasingly negative and critical of their presence on the campaign trail. These changes can

\footnotetext{
${ }^{1}$ The title of an article about Clementine Churchill in the Daily Mail, December 3 1923: 10

${ }^{2}$ Daily Mail, $12^{\text {th }}$ April 2010, p.7
} 
be seen to take place over three distinct periods within the sample period; the interwar years (1918-45), where wives enjoyed an actively political role on the campaign trail, the post-war period (1950-1983), where coverage began to focus explicitly on leaders' spouses and their private experiences of political office, and the more recent period (1987-2010), where wives who remained passively non-political were celebrated while those deemed too influential are criticised. These changes will firstly be demonstrated in relation to the content analysis. Specific qualitative examples will then be discussed in chronological order in order to show their development over time.

Due to the large sample size associated with this research. It is necessary to demonstrate the extent to which the trends discussed in the qualitative analysis are representative of the entire sample. This is achieved by referring to three specific measures from the content analysis. Firstly, Figure 1 shows the percentage of items about relatives which depict them actively campaigning. Such behaviour is most visible during the interwar years and it declines sharply. Therefore, early relatives were more likely to be overtly politically engaged. Examples of the tone of this coverage will be discussed in the next section.

Figure 1: Percentage of items about relatives focused on active campaigning, 1918-2010 


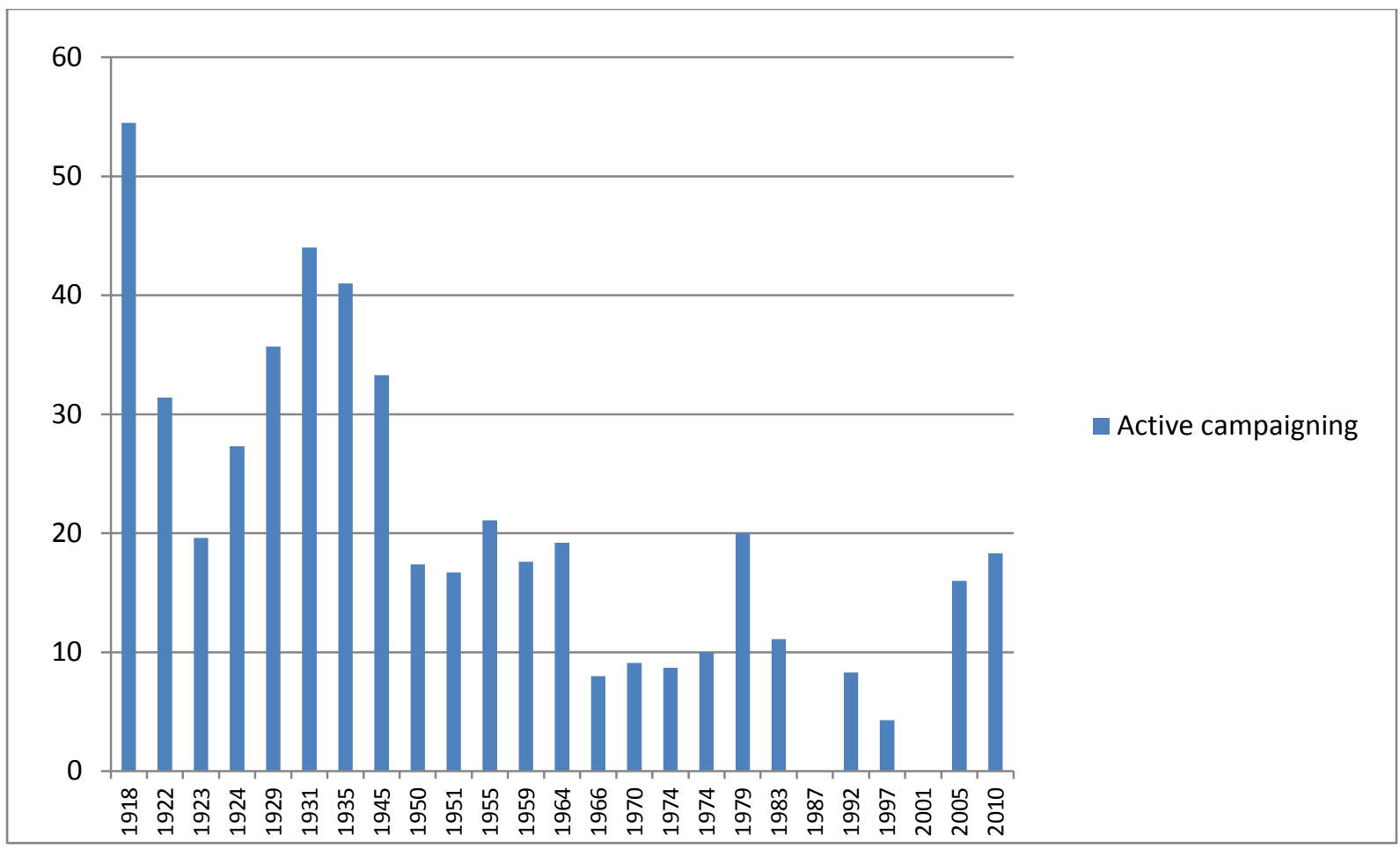

The decline in overt political campaigning in the post-war period means that the news coverage of political relatives changes dramatically. Figure 2 shows that around the same time, there is an increase in the percentage of items that instead focus upon their personal lives and experiences.

Figure 2: Percentage of items about relatives focused on personal lives, 1918-2010 


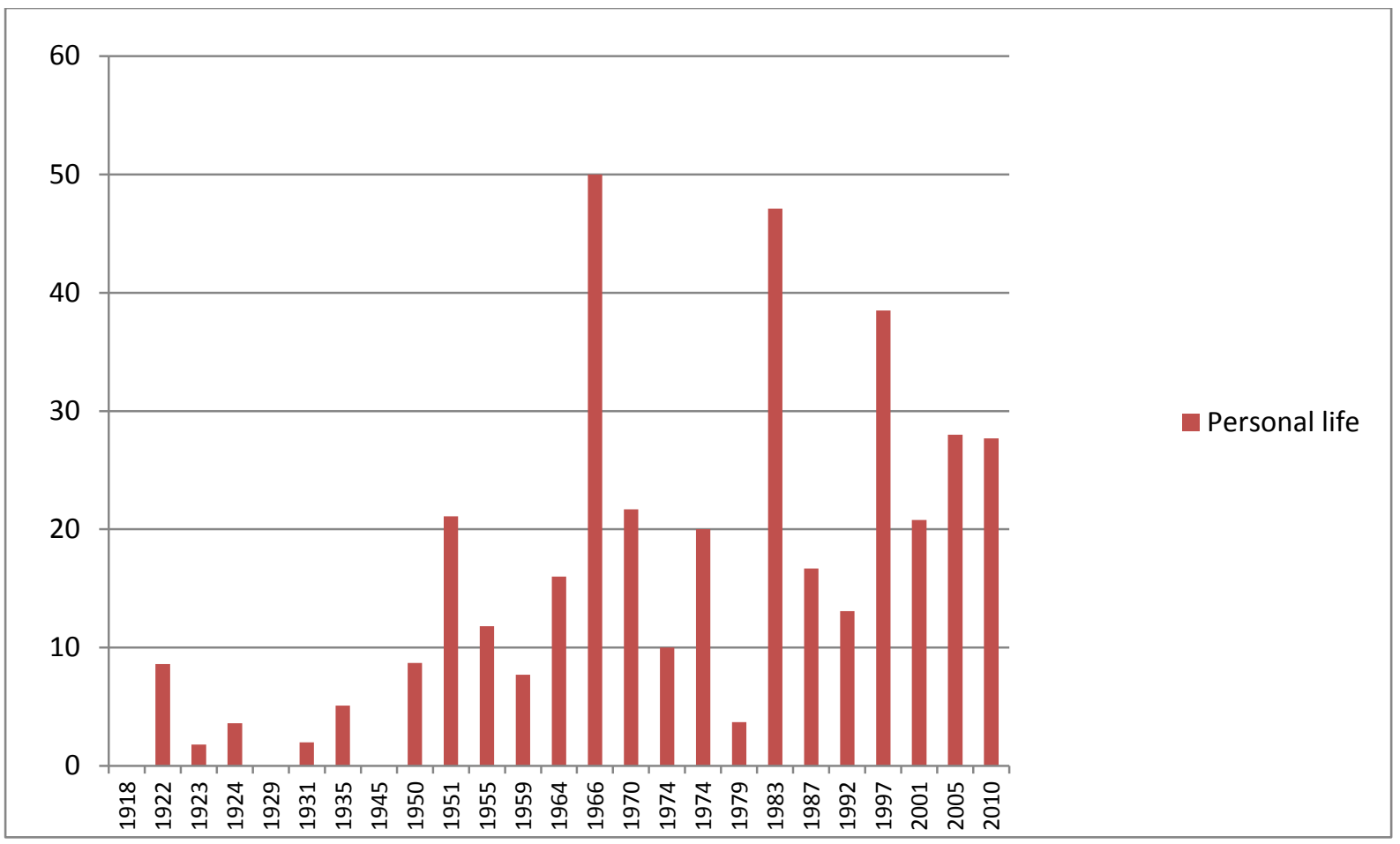

This change in focus means that the role of relatives in political discourse has changed from being political actors who are seen as important for communicating with women voters to representing their relatives’ political appeal in a more informal way.

The increase in negative coverage in the latter elections can clearly be observed in Figure 3.

Figure 3: Percentage of items containing negative evaluations of relatives’ 1918-2010 


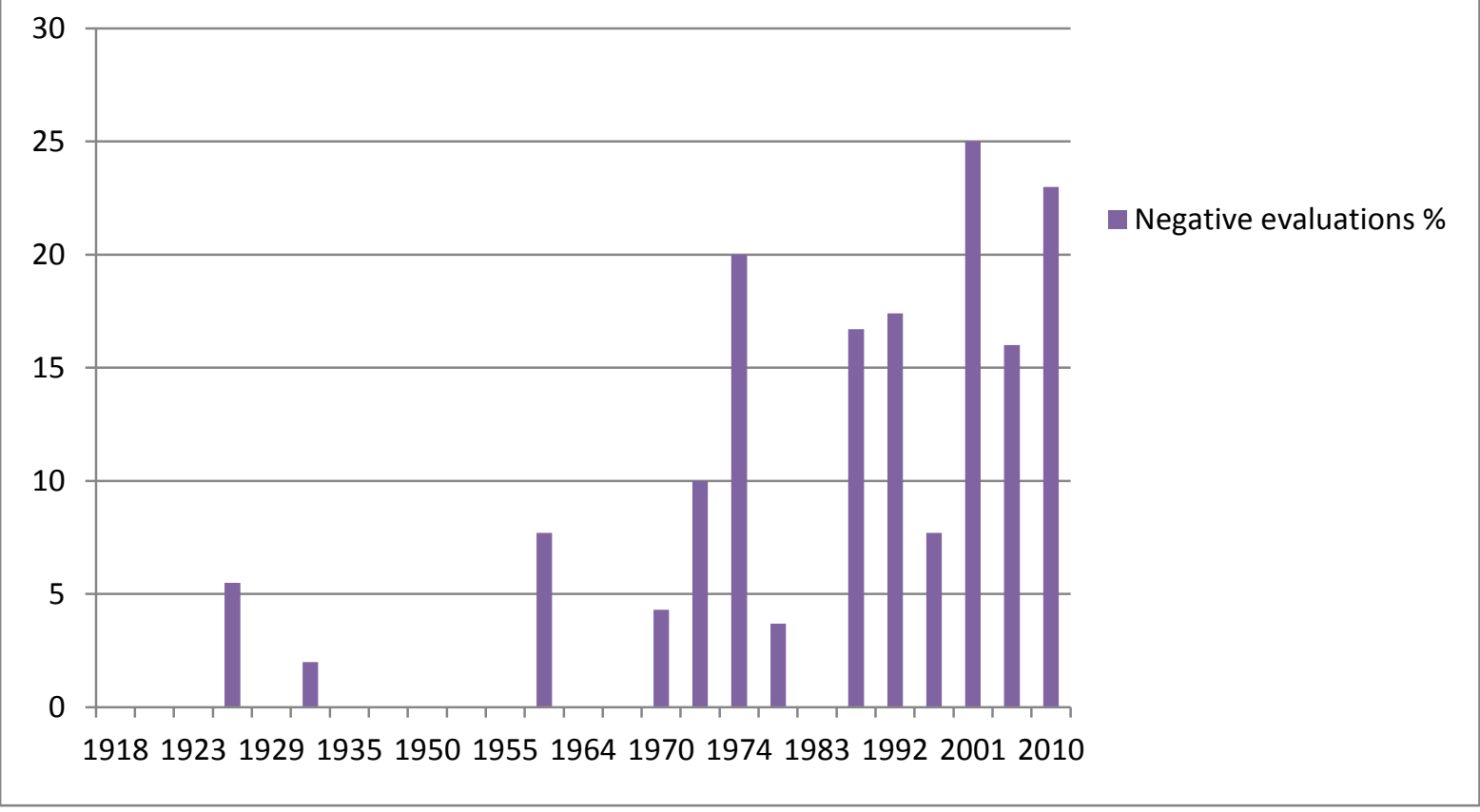

Figure 3 shows that during the early elections, overtly negative criticism of the activities of politicians' relatives was extremely rare and this endures well into the 1960s. Negative evaluations of relatives then start to emerge in the 1970s where, apart from 1983, they become a regular aspect of the coverage. The nature and tone of these changes in the political coverage of relatives will now be discussed in relation to specific qualitative examples. Many of the women who appear in the qualitative discussion are lost to history in that they were the wives or daughters of minor candidates. The politician and political party they represented is given when known.

1918 - 1945: "Ideal political wife" $\underline{3}$

When women were enfranchised in 1918, relatives were perceived as important conduits for the promotion of party political agendas to female citizens. There was a shift

\footnotetext{
${ }^{3}$ The title of an article about Clementine Churchill in the Daily Mail December 3 1923: 10
} 
away from passively supportive wives, which was made explicit in The Guardian: “a generation ago it was thought desirable for the wife of a candidate to make a personal tour in her husband's constituency... it was an appeal from woman to woman; an appeal based entirely on sentiment, heedless of reason and of policy” (The Guardian, 1923c) since women could not vote themselves and could only encourage their husbands: "but it is no longer enough for her to look charming. She must understand the issues and be able to explain and justify her husband’s policy” (he Guardian, 1923c). The notion that politicians’ wives had an important role in communicating with women voters was widespread across the press. For example, the Daily Mail argued women voters "feel instinctively that they will learn more about their candidate by studying the sort of woman he has married than by listening to his devastating lists of import and export statistics” (Daily Mail, 1923).

During the interwar period there was a multitude of newspaper reports chronicling the activities of candidates’ wives when they addressed women only campaign meetings. Examples included “Mrs C.F.G Masterson [who] had a friendly reception from a crowded meeting of women electors” (The Guardian, 1924); or Lady Diana Cooper who reportedly "faced an audience of 4000 women yesterday at Oldham, where she is helping her husband" (Daily Mail, 1924). They were also granted space in newspapers to address women voters directly, such as "the wife of the Minister of Transport and one of the most active women workers in the Conservative Party” (Daily Telegraph, 1929) who wrote an article addressed to women urging them to think "seriously how they intend to vote tomorrow." Many of them publicly discussed party policy and were portrayed as being well-versed in the important issues of the day. One example was "Mrs Barclay [who] attacked the Conservative Party vigorously for their educational economies and finished up with a hope that 'the grave of Protection will this time be dug so deep that its corpse will not be dug up again by any Conservative body snatchers” (The Guardian, 1923b). Furthermore Lady Ernest Simon 
(whose husband was a Liberal MP) reportedly lambasted “the government's treatment of education, which I feel to be the most fundamental of all social questions” (The Guardian, 1935). There are frequent examples of female relatives campaigning actively on a range of policies during the interwar period.

These interventions were largely construed as positive and important events by the newspapers which praised their campaigning capabilities; for example, former Liberal Prime Minister Herbert Asquith’s wife “ seems to have performed a notable feat in the way of quelling rowdyism (sic) at one of her brother’s meetings on the Clyde” (The Guardian, 1923a), while Clementine Churchill's (wife of Winston) grasp of economics encouraged the Daily Mail to comment that "the British fiscal system does not sound a bright topic for a woman speaker till Mrs Churchill puts on her cooking sleeves and begins to make rissoles of Mr Baldwin’s programme” (Daily Mail, 1923). Despite the generally positive constructions of female politicians' wives, the gendered nature of their construction is inescapable. As this last quotation demonstrates, the contribution made by these women was couched in gendered terms by using the language of domesticity. Mrs Churchill's argument against the economic policy espoused by the Conservative leader is represented by a food preparation metaphor, which reminds readers of the traditional wifely domain. This type of language was also attributed directly to those women who made political speeches, such as when Mrs NortonBarclay declared that Sir Edwin Stockton's speech (which left out an important contemporary issue like Free Trade) "reminded her of the girl who tried to make Irish stew. She left the meat out” (The Guardian, 1923b).When Mrs Masterson remarked about proposed tariff reforms that "you can no more give Imperial Preference without taxes on food than you can

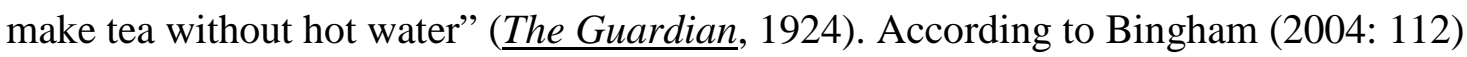
“attempts were made to develop new forms of political discourse that would engage the female voter, which usually involved translating issues into the language of housewifery or 
motherhood" and the inclusion of these references in the women's remarks goes some way to support this argument. The campaigning efforts of female relatives in the interwar years were largely welcomed by the press, although their contributions were nevertheless portrayed as traditionally feminine and therefore unthreatening to the status quo.

In this period, newspapers frequently portrayed politicians’ wives as actively engaging in the political campaigns of their husbands and other men; furthermore, this was represented as an effective means of engaging with the new women voters. Newspaper coverage explicitly recognised the virtues of these women engaging in political campaigning, but their contributions remained gendered in that their reported activities were designed to appeal primarily to women voters. This reflects Jalland's (1986) observation that politicians' spouses became more heavily involved in campaigning at the beginning of the twentieth century.

1950 - 1983: "On the platform in the background" 4

After the Second World War, wives continued to be constructed as helpful companions, but there is a shift away from explicit political campaigning marked by an increase in items where they simply accompany their husbands on the campaign trail. An example would be former Labour Prime Minister Clement Attlee’s wife Violet, who “contrived to arrive everywhere looking immaculate. The secret was a small travelling iron, with which she pressed her clothes each night and renewed the crease in the Prime Minister's trousers” (Daily Herald, 1950). Similarly, Dora Gaitskell (wife to former Labour leader Hugh Gaitskell) is described as "ready for anything. Yesterday morning she spent an hour having a special hair-do. Then, with a brand new red ribbon round her hat, she joined her husband on

\footnotetext{
${ }^{4}$ Mary Wilson quoted in Daily Mirror, $25^{\text {th }}$ March 1966, p.17.
} 
his rounds” (Cook, 1959). As these examples demonstrate, the gendered coverage continues unabated with much attention given to their domestic responsibilities and their credentials as ideal companions on the campaign trail. Again, though, here is a definite shift from the former focus on their overtly political role. The decline in women-only meetings during this period may help to account for the drop-off in their actual campaigning, as well as the subsequent reporting of their political activities (Lawrence, 2009).

What is perhaps most striking about this period is the increased attention given to these women's private lives, and their experiences as the wife of a Prime Minister or party leader in particular. Clementine Churchill and Violet Attlee were both interviewed by the

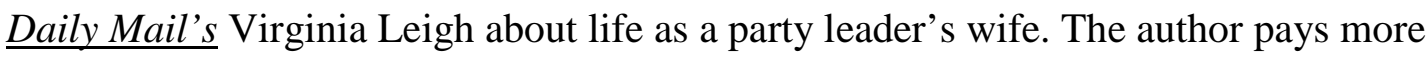
attention to aspects of their private lives than their role in the campaign. The familial responsibilities of both women were emphasised: "as well as being a wife, she [Clementine Churchill] has been a mother. There were Randolph, Diana, Sarah and Mary to be managed! But these are comparatively easy tasks, if you can imagine it. Her main concern has always been that Winston himself should not be overworked” (Leigh, 1950). Violet Attlee on the other hand "told me frankly that it had been difficult bringing up her children also (three girls, one boy) while their father was in public life all the time” (Leigh, 1950). This piece plays down their political views, concentrating instead on their roles as dutiful wives and caring mothers. This distinctly non-political role is further exemplified by the assertion that "rarely do the Attlees at home discuss politics, they usually talk about books and literature" (Leigh, 1950). Violet Attlee’s own political views were in fact quite opposed to her husband's, as she voted Conservative, though this was not reported at the time (Seaton, 2003). Mary Wilson (wife of Labour Prime Minister Harold Wilson) was similarly interviewed in the Daily Mirror in 1966 about her experiences as the Prime Minister's wife. She too received highly personalised coverage. She was praised for being "reflective, 
sensitive, self- analytical” (Proops, 1966) and for being a "passionately devoted mother” (Proops, 1966). Mary Wilson is constructed as being very clear that her role as Prime Minister's wife is not a political one: she stated that "there are plenty of people around to advise him and discuss things with him...that’s not for me to do” (Proops, 1966) thus presenting herself as a traditional wife who is there to support her husband, rather than have her own agenda.

The role of the politicians' wife was frequently discussed by the newspapers during this post war period. According to one politicians' wife: “there are two main activities for candidates' wives - canvassing and making little speeches from the platform. The first is said to be invaluable” (Mayhew, 1959). She also warned that speeches could be hazardous and that it was important to avoid "simpering how delightful your husband is and therefore how excellent a representative he will be” (Mayhew, 1959). Wives were ultimately meant to “boost your husband’s image at all times” (Leslie, 1974), which invariably meant “project[ing] an image of happy domesticity” (Leslie, 1974) and ensuring that they looked presentable at all times. Arriving anywhere “windblown and dishevelled” (Mayhew, 1959) would render them “no credit to the candidate at all” (Mayhew, 1959). Mary Archer (wife of then Conservative MP Jeffrey Archer) claimed in the Daily Mail that "mostly you're just required to sit on a platform and smile” (Leslie, 1974). This sentiment was shared by Conservative Prime Minister Anthony Eden’s wife Clarissa who remarked about her role during the 1955 general election that: "all I had to do was keep smiling” (quoted in Booth and Haste, 2005, p.17). Winfield (1997) notes that accompanying the candidate on the campaign trail was one of the most important functions of an American political wife. The behaviour of post-war politicians' wives was summed up somewhat derisively by the Daily Mail as a “cliché-uttering, hand-shaking, all-smiling, all-purpose wind up political doll: brand name 
The Candidate's Wife” (Leslie, 1974) who “needn’t know much about politics, but she must know her place...a few discreet and worshipful paces behind her husband” (Leslie, 1974).

During this period, newspaper coverage of politicians’ wives becomes specifically focused on their personal experiences of public life, and their political views are absent. Instead their role is to enhance the image of their husband through shedding light on his personal achievements and attributes. Borelli (2011) argues that politicians’ wives are supposed to enhance the role of their husbands by representing her dedication to their shared domestic lives. This firmly positions her in the private sphere, in order to underline his commitment to the political sphere. That this should be happening at a time when feminists were agitating for a wider definition of what can legitimately be considered political is particularly interesting and suggests the complexities involved in attempting to counter traditional patriarchal political discourses.

\section{7 - 2010: "The Spectre of Lady Macbeth" $\underline{5}$}

The image of politicians' wives as passive and loyal supporters who refrained from presenting political messages had become so well established in newspaper discourse, that when women once again emerged who were deemed to transgress this norm they received negative responses from the press. Despite evidence of previous criticism, in a number of cases during the late 1980s and 1990s this turned into outright hostility. This was particularly the case with certain women expressing their own political views or actively involving themselves in campaigns. Relatives who chose to take a merely supportive, nonspeaking role on the campaign trail were celebrated as the ultimate political companion: neatly illustrated by Lynda Lee-Potter of the Daily Mail when she remarked that then Conservative Prime

\footnotetext{
${ }^{5}$ 'The week the first ladies went mad', The Guardian, $5^{\text {th }}$ May 2005, p.10
} 
Minister John Major’s wife Norma and Cherie Blair had "been on the election trail from dawn 'til dusk, but have continued to look radiant, immaculate, merry-hearted, confident, loving and loyal... and have kept their opinions to themselves” (Lee-Potter, 1997). Similarly positive coverage praised former Conservative Party leader William Hague’s wife Ffion for being “a strong, clever woman who is also in many ways a traditional wife” (Lee-Potter, 2001) who "may rarely open her mouth in public” (Glover, 2001). These examples clearly indicate that, for the press, the idealised role of a party leader's wife which started to take precedence in the 1950s has become one where the women in question follow their husbands on the campaign trail, eschew giving political opinions and loyally support her husband's political ambitions. This may be why both Sarah Brown (wife of then Prime Minister Gordon Brown) and Samantha Cameron (David Cameron's wife) were used strategically to counter the perceived faults of their husbands and to humanise and soften their public images during the 2010 election (Higgins and Smith, 2013).

Negative scrutiny of the campaigning activities of politicians' wives turns to outright hostility in the case of some women politicians who caught the attention of the press. The newspapers are especially critical of attempts to cultivate an image which they perceive to be somehow inauthentic. Such criticism followed Cherie Blair after her initial success in gaining positive coverage during the 1997 election campaign. During the 2001 and 2005 elections she was derided for "conjur[ing] an image of the dutiful housewife keeping the children quiet as Daddy worked hard in the study, while seeming to forget that she has a job too” (Freeman, 2005) or as the Daily Mail put it "Mrs Blair...dropped the wigged Cherie Booth QC side of her identity” (Letts, 2005) in order to present herself as an ordinary wife. Such behaviour is characterised as being merely a performance designed for "smoothing down of her voterscaring sharp edges” (Freeman, 2005). 
An inherent part of the criticisms levelled at Cherie Blair is the perception that she is too overtly political and is therefore wielding illegitimate power over the democratic process. The fact that she "stood as a Labour candidate in the Kentish marginal Thanet North in 1983" (Evison, 1997) coupled with the notion that she was "a feminist with Left-wing leanings" (Evison, 1997) meant that the press began to construct her as a political liability. Blair was transformed from being “every inch a budding Prime Minister’s wife” (Maung, 1997) in 1997 to “the Conservative Party’s single greatest vote-winner...demonstrating what a political liability she is to Labour” (Letts, 2005) by 2005. To underline this view, The Daily Telegraph's claimed that "a YouGov poll in 2002 placed her four times more likely than Sandra Howard [the wife of her husband's opposition rival] to turn voters away from her husband” (Hollingshead, 2005). Cherie Blair ultimately came to be constructed, particularly by conservative newspapers, as "somewhat overbearing, forever barging into the conversation and letting some new clanger drop from that infamous mouth” (Letts, 2005).

Another wife who caused anger for airing her own political views was Glenys Kinnock (wife of former Labour leader Neil Kinnock). She was criticised in the Daily Mail for embarking on her own tour of constituencies in the 1992 election. "During the last four weeks she has visited well over 30 constituencies. She's campaigned relentlessly on her own” (Lee-Potter, 1992). The appearance that a leader’s wife would have her own political views and agenda was presented as suspect behaviour that ought not to be tolerated. These more overtly political wives were constructed as somehow dangerous not only to their husband's political careers, as previously discussed, but also to democracy. Throughout this period there was a growing tendency to equate confidence and intelligence in a politician's wife with notions of manipulation and ambition for power in their own right. The Daily Mail columnist Lynda Lee-Potter illustrated this with her remark that Glenys Kinnock is "the possessor of what an interviewer in a Labour newspaper described as 'staggering self-assurance.' It's the 
quality in her that disturbs me the most” (Lee-Potter, 1992). Embedded in such discourses was the suspicion that these women would have undue influence over their partners if elected. Lee-Potter explicitly stated “ make no mistake about it, we don’t just consider Kinnock the man but Kinnock the woman, because Glenys’s (sic) voice at Number 10 would be loud and forceful” because she "almost certainly wants...power, a voice, her own way" (Lee-Potter, 1992). Cherie Blair was similarly accused of being "the real power behind 'our Tone’” (Evison, 1997).

Such coverage reinforces Reyes (2003: 36) argument that "the right wing media has consistently presented Cherie as a 'highly political and public spouse, deploring her left-ofTony past and her career as a QC 'profiteering' from the Human Rights Act”, in order to discredit Tony Blair's government. Such coverage reveals the ease with which "the spectre of Lady Macbeth is eerily invoked by the press” (Freeman, 2005) and echoes the extent to which women like Hillary Clinton have been vilified in the US for their activism and unwillingness to behave like a traditional wife (Brown and Gardetto, 2000; van Zoonen, 2005). This is perhaps because any political or public activity conducted by politicians’ wives may undermine a party leader's position, through engaging in traditionally masculine behaviour which challenges his role as the public member of their private partnership (Borelli, 2011).

Clearly, throughout the 1990s and 2000s the role of being a party leader's spouse has changed considerably since the interwar years. The newspapers were keenly aware that from now on "the media will always be a fickle beast for political spouses" (Hollingshead, 2005) and that their treatment throws up a host of contradictions which women are particularly susceptible to; being a politician's wife is “a role that shows up more than any other the quite frankly ridiculous standards to which women in the public eye are held: if they are silent they are dull; if they talk, they are risky loose cannons. If they are successful career women, they 
are not supportive of their husband; if they are mutely adoring, they are dull and old fashioned” (Freeman, 2005). This disparity between the positive coverage of traditionally feminine behaviour and negative criticism of those who transgress these standards is neatly illustrated by the case of former Liberal Democrat leader Nick Clegg’s wife Miriam Gonzalez Durantez during the 2010 campaign. She was critical of press coverage of herself and the other wives and actively complained about the attention they were receiving, branding it frivolous and patronising (Swaine, 2010). She was much admired by the newspapers for keeping a lower profile than the other two party leaders' wives and for "not forsaking her career for her husband's” (Moir, 2010c). The Daily Mail praised her for "acting like an independent, modern mother and wife” (Tyler, 2010), who supported "her husband in a way that is loyal and enthusiastic, but not demented” (Moir, 2010a). The coverage of Miriam changed however when she became more involved with the campaign and she too became vilified for intruding into the political sphere: "she became just another political wife; engaging in photogenic but laughably unlikely things, all in the name of vote catching” (Moir, 2010b).

The rightful role of politicians’ wives was emphasised by Gordon Brown’s comments about his own wife: “she’s doing a great job as a mother and she’s doing a great job as a wife and I think it's quite unfair [to criticise her] because she's not throwing herself out with political views” (Kirkup, 2010) Explicitly emphasising a non-political role for politicians’ spouses during the 2010 campaign suggests an active attempt on the part of politicians and media alike to distance these particular women from being perceived as too influential, like Cherie Blair. Winfield and Friedman (2000) make a similar argument about the retraditionalisation of women like Lynne Cheney and Tipper Gore during the 2000 US Presidential election, suggesting that these women tried to avoid being cast in a similar role to Hillary Clinton. 


\section{Conclusion}

The mediated representation of politicians' wives has changed considerably between 1918 and 2005 and in sometimes unexpected ways. The function of these women in the coverage changed considerably; during early elections a number of wives were portrayed as active political campaigners and they received a favourable response to their political undertakings on behalf of their respective candidates. These women would have been portrayed in this fashion because women's political activism before they gained the vote is well documented (Cowman, 2010), and therefore this would possibly have been seen as normal to contemporary audiences and journalists who were used to organisations such as the Primrose League campaigning on behalf of their respective political parties. Moreover, wives were viewed as an important means of appealing to women voters, especially given the relatively low numbers of women candidates standing for parliament during this period (Cowman, 2010), which means they were an important part of the campaign and therefore were not viewed as transgressing gender norms.

During the interwar years they were constructed as being important political messengers for the newly enfranchised women voters. After the war, their representation becomes increasingly more personalised and de-politicised, with the emphasis shifting to their personal experiences of being on the campaign trail and indeed in public life generally. Furthermore, the coverage became much more focused just on the wives of the party leaders during this period. This is perhaps due to the increased focus on party leaders, and also due to the increased importance of the personal lives of politicians, and by extension, that of their families in political communication (see Langer, 2012 and Stanyer, 2013). These women were celebrated for their largely supportive and non-political role as wives accompanying 
their spouse on the campaign trail, thus enhancing the masculinity of their spouses by behaving in traditionally feminine ways.

By the late 1980s and 1990s the newspapers once again constructed some of these women as politically engaged. However, the tone of the coverage is different from earlier examples. Instead of their political interest being greeted as helpful to their relatives' political ambitions, their political views were portrayed as dangerous and undesirable. The political activism of Glenys Kinnock and Cherie Blair in particular was represented as an illegitimate activity for the mere relatives of politicians. The threat they supposedly pose as unelected influences on their spouses was moreover constructed as an issue of public concern in certain newspapers. Such discourses were mainly confined to tabloids like the $\underline{\text { Daily Mail and } \underline{\text { The }}}$

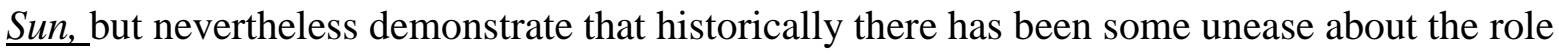
of relatives in politics. The way in which the mainstream parties sought to present their relatives as supportive followers rather than political campaigners during the 2010 elections perhaps suggests that this concern has been heeded by political elites. The 2010 version of party leaders' wives could not be accused of being either too political or too feminist, with the focus on their familial roles and clothing choices which suggests a conscious effort to distance them from women like Cherie Blair. Similar observations were made about the wives of presidential candidates in the US who sought to present themselves as less threatening than Hillary Clinton (Brown and Gardetto, 2000).

In a sense, this recent de-politicisation in terms of formal politics was accompanied by a re-politicisation as symbolic socially conservative resources through which male politicians can demonstrate their personal credentials. This same phenomenon seems to be evident once again in the coverage of the 2010 election, where the leaders' wives were presented as retraditionalised and non-political supporters of their husbands’ political ambitions. The political influence of these women is therefore constructed in traditionally feminine terms, 
meaning that although these women are not making formal political statements, they are informal representatives of their husband's political values. This reinforces the notion that women contribute to politics through their attachment to the informal private sphere, and can also be seen as an attempt, in Borelli's (2011) terms to enhance the image of their husbands by preserving their masculine public appeal.

What remains unclear is exactly why the attitudes of the press have changed so much. Where once an intelligent, politically-engaged wife was viewed as an asset to help politicians communicate with women voters, it is now viewed as dangerously undemocratic for unelected women to espouse political views or attempt to assist her husband in political terms. One explanation may be that the increase in female politicians who are supposed to take on the role of representing and communicating with women voters has meant that relatives are no longer seen as legitimate political actors in their own right. Another reason could be that the 1980s and 1990s saw a period of intense backlash against the achievements and aims of the feminist movement which could have translated into the desire to return such women to a less public role. This could be seen as evidence of a backlash or growth in postfeminist discourse within the news media which has been observed in other works (see Mendes, 2011; McRobbie, 2009). What this article has made clear, however, is that the representation of politicians’ wives in political coverage deserves more attention from academic research that it currently receives, as they clearly perform some kind of gendered political role in electoral politics as far as politicians and newspapers are concerned.

\section{$\underline{\text { References }}$}

Adcock, Charlotte (2010) 'The Politician, The Wife, The Citizen, And Her Newspaper: Rethinking women, democracy, and media(ted) representation', Feminist Media Studies, 10(2): 135-159. 
Beasley, Maurine H. (2005) First Ladies and the Press: The Unfinished Partnership of the Media Age. Evanston: Northwestern University Press

Bingham, Adrian (2004) Gender, Modernity, and the Popular Press in Inter-war Britain, Oxford: Oxford University Press

Booth, Cherie and Haste, Kate (2005) The Goldfish Bowl: Married to the Prime Minister 1955-1997, London: Vintage

Borrelli, Mary Anne (2011) The Politics of the President's Wife. College Station: Texas A\&M University Press

Braden, Maria (1996) Women politicians and the media. Lexington: University of Kentucky

Brown, Mary Ellen and Gardetto, Darlaine (2000) 'Representing Hillary Rodham-Clinton:

Gender, Meaning and News Media’, Sreberny, Annabelle and Van Zoonen, Liesbet (eds)

Gender, Politics and Communication, Cresskill, NJ: Hampton Press

Cinar, Meral Ugur (2014) 'Construction of Gender and National Identity in Turkey: Images of the First Lady in Turkish Media (2002-7)', Middle East Studies 50(3): 482-492

Cook, Arthur (1959) ‘Gaitskell looks up his train’, Daily Mail October 8: 7

Cowman, Krista (2010) Women in British Politics, c.1689-1979, Basingstoke: Palgrave MacMillan

Daily Herald (1950) 'Notebook’, Daily Herald February 20: 2

Daily Mail (1923) ‘Ideal election wife’, Daily Mail December 3: 10

Daily Mail (1924) 'Lady Diana Cooper’, Daily Mail October 23: 6

Daily Telegraph (1929) 'Women and their vote', Daily Telegraph May 29: 10

Evison, Sue (1997) ‘Britain’s First Lady’, The Sun May 1: 31

Freeman, Hadley (2005) 'The week the first ladies went mad', The Guardian May 5: 10

Gill, Rosalind (2007) Gender and the Media. Cambridge: Polity Press 
Glover, Stephen (2001) ‘The Last Stand’, Daily Mail June 2: 13

Halevi, Sharon (2003) 'She Who Must Be Obeyed: The Media and Political Spouses in Israel', Women's Studies in Communication 26(2): 165-190

Higgins, Michael and Smith, Angela (2013) 'My husband; my hero’: selling the political spouses in the 2010 general election, Journal of Political Marketing 12(2-3): 197-210

Holland, Pat (2004) The Politics of the Smile: 'Soft news' and the Sexualisation of the Popular Press, in Carter, Cynthia and Steiner, Linda (eds) Critical Readings: Media and Gender. Maidenhead: Open University Press

Hollingshead, Iain (2005) 'A quiet life on the fringes of power', Daily Telegraph May 3: 15 Holtz-Bacha, Christina (2004) Germany: How the private life of politicians got into the media, Stanyer, J. and Wring, D. (ed.) Public Images, Private Lives: An Introduction, Parliamentary Affairs 57(1): 41-52.

Ibroscheva, Elza (2013) 'The First Ladies and the Arab Spring: A textual analysis of the media coverage of the female counterparts of authoritarian oppression in the Middle East', Feminist Media Studies 13(5): 871-880

Jalland, Pat (1986) Women, Marriage and Politics 1860-1914. Oxford: Oxford University Press

Kirkup, James (2010) 'Brown wants to do charity work’, Daily Telegraph May 5: 5

Kuhn, Raymond (2004) 'Vive la difference’? The Mediation of politicians’ public images and private lives in France, Stanyer, J. and Wring, D. (ed.) 'Public Images, Private Lives: An Introduction’, Parliamentary Affairs 57(1): 24-40

Landes, Joan B. (1998) Feminism, the Public and the Private. Oxford: Oxford University Press

Langer, Ana Ines (2012) The Personalisation of Politics in the UK: Mediated Leadership from Attlee to Cameron, Manchester: Manchester University

Lawrence, Jon (2009) Electing Our Masters: The Hustings in British Politics from Hogarth to Blair, Oxford: Oxford University Press 
Lee-Potter, Lynda (1992) 'Glenys flirts, but her eyes are cold’, Daily Mail April 8: 7

Lee-Potter, Lynda (1997) 'Winning Wives’, Daily Mail April 30: 11

Lee-Potter, Lynda (2001) 'For the love of Ffion’, Daily Mail June 5: 16-17

Leigh, Virginia (1950) 'The leading ladies of the poll’, Daily Mail February 23: 4

Leslie, Ann (1974) ‘The Candidate’s wife’, Daily Mail October 8: 12

Letts, Quentin (2005) 'The man who took this country to war chatted about how many times a night he can manage to have sex with Cherie’, Daily Mail May 5: 6-7

Lister, Ruth (1997) Citizenship: Feminist Perspectives. Basingstoke: MacMillan

Maung, Carole Aye (1997) 'My Cherie Amour’, Daily Mirror April 29: 3

Mayhew, Christopher (1959) 'The candidate’s wife’, The Guardian October 2: 8

McRobbie, Angela (2009) The Aftermath of Feminism: Gender, Culture and Social Change. London: Sage

Mendes, Kaitlynn (2011) Feminism in the News: Representations of the Women's Movement since the 1960s. Basingstoke: Palgrave MacMillan

Moir, Jan (2010a) ‘No wonder Sam Cam’s hair is standing on end!', Daily Mail May 3: 8-9 Moir, Jan (2010b) ‘Now pass me that boulder, compadre’, Daily Mail April 12: 7

Moir, Jan (2010c) 'War of the Wives', Daily Mail April 8: 7

Norris, Pippa (1997) Women, Media and Politics. Oxford: Oxford University Press

Page, Ruth E. (2003) ‘Cherie: Lawyer, wife, mum’: contradictory patterns of representation in media reports of Cherie Booth/Blair, Discourse and Society 14(5): 559-579

Proops, Marjorie (1966) ‘Ssh...he’s having a little nap in the other room’, Daily Mirror March 24: 17

Reyes, Oscar (2003) ‘Cheriegate! Celebrity, scandal and political leadership’, Mediactive 2: 26-43 
Ross, Karen (2002) Women, Politics, Media: Uneasy Relations in Comparative Perspective. Cresskill, NJ: Hampton Press

Scharrer, Erica and Bissell, Kimberley (2001) Overcoming Traditional Boundaries: the role of political activity in the coverage of recent first ladies, Women and Politics 21(1): 55-83

Seaton, Jean (2003) Public, Private and the Media, The Political Quarterly 74: 174-183

Seymour-Ure, Colin (2003) Prime Ministers and the Media: Issues of Power and Control, Oxford: Blackwell

Sreberny-Mohammadi, Annabelle and Ross, Karen (1996) 'Women MPs and the Media: Representing the Body Politic'. Parliamentary Affairs 49(1): 103-115

Stanyer, James (2007) Modern Political Communication. Cambridge: Polity Press Stanyer, James (2013) Intimate Politics: Publicity, Privacy and the Personal Lives of Politicians in Media-Saturated Democracies. Cambridge: Polity

Siltanen, Janet and Stanworth, Michelle (1984) Women and the Public Sphere: A critique of sociology and politics. London: Hutchinson

Swaine, Jon (2010) 'Yes, you can call me sexy, says Mrs Clegg’, Daily Telegraph April 13: 7

The Guardian (1923a) 'Miscellany’, The Guardian November 30: 7

The Guardian (1923b) ‘Mrs Barclay’s explanation of an “unnecessary election”, The Guardian December 1: 13

The Guardian (1923c)‘The problems of the election. Is there a woman’s point of view?', The Guardian November 30: 6

The Guardian (1924) 'Women and food taxes. Mrs Masterson’s address at Levenshulme’, The Guardian October 23: 11

The Guardian (1935) ‘Lady (Ernest) Simon’s decision’, The Guardian November 9: 15 Tyler, Alison (2010) ‘Miriam’s our ideal woman’, Daily Mail April 19: 39 
Van Zoonen, Liesbet (1998) 'The Ethics of Making Private Life Public', in Brants, Kees, Hermes, Joke and van Zoonen, Liesbet (ed) The Media in Question: Popular Cultures and Public Interests. London: Sage, 113-123

Van Zoonen, Liesbet (2005) Entertaining the Citizen, Oxford: Rowman and Littlefield Winfield. Betty Houchin (1997) The First Lady, Political Power, and the Media: Who Elected Her Anyway?, Norris, Pippa (ed.) Women, Media and Politics, Oxford: Oxford University Press pp.166-179

Winfield, Betty Houchin and Friedman, Barbara (2003) Gender Politics: News coverage of the candidates' wives in campaign 2000, Journalism and Mass Communication Quarterly 80(3): 548-566 